\title{
PROSPECTIVE PRE-SCHOOL TEACHERS' VIEWS ON STEM LEARNING IN GRADE 9: THE PRINCIPLE OF CONTINUITY IN EDUCATION
}

\author{
Dagnija Cedere, Inese Jurgena, Rita Birzina, Sandra Kalnina \\ University of Latvia, Latvia \\ E-mail: dagnija.cedere@lu.Iv, inese.jurgena@lu.Iv, \\ rita.birzina@lu.Iv, sandra.kalnina@lu.lv
}

\begin{abstract}
The life quality of society and the stability of national economy is largely connected with science, technology, engineering, and mathematics (STEM). The complex character of STEM education demands informed teaching/learning strategies in order to make the $21^{\text {st }}$ century youth interested in learning. The aim of the research was to find out the views of prospective pre-school teachers on Grade 9 students' STEM learning, thus addressing the topical principle of continuity in education. A survey of 261 prospective pre-school teachers of the University of Latvia was performed. The obtained results show that in general the prospective pre-school teachers have some notion about the level of teaching/learning requirements in Grade 9 of the basic school, the integration of STEM and teaching/learning strategies. They acknowledge cognitive interest, inquiry-based learning and the importance of STEM knowledge and skills in the national development as significant, but little value is given to the exploration of nature in out-of-school time and to the importance of mathematical skills. More experienced respondents assess STEM learning higher. The given research raises the issue of the principle of continuity in education and gives a possibility to understand better the needs of prospective teachers in order to improve teacher education programs at the University.
\end{abstract}

Keywords: cognitive interest, continuity of education, prospective pre-school teachers, STEM learning

\section{Introduction}

Science, technology, engineering, and mathematics (STEM) is an important part of general education that constitutes the necessary people's knowledge and skills of our future society. Therefore, the teaching/learning process has to be organized in such a way that the child's/learner's development proceeds through successive stages of education, and the learning is harmonized according to the principle of continuity in its broadest sense. Positive experience in the field of STEM gained in early childhood serves as a basis for further meaningful STEM education. Lately, the idea that children's early education - a stage before the primary education - lays foundation for lifelong learning and development (Eurydice Report, 2019) has been actualized.

\section{Research Problem}

Science, technology, engineering, and mathematics education is important for learners to succeed in future. Implementing STEM education there are more possibilities to help learners to develop relevant topical skills: critical thinking, problem solving, decision making, learning to learn, communication, collaboration, teamwork (Barcelona, 2014; Binkley et al., 2012; 
Dagnija CEDERE, Inese JURGENA, Rita BIRZINA, Sandra KALNINA. Prospective pre-school teachers' views on STEM learning in grade 9: The principle of continuity in education

PROBLEMS

OF EDUCATION IN THE $21^{\text {st }}$ CENTURY Vol. 80, No. 1,2022

Maass et al., 2019; Tytler, 2020). STEM education has grown significantly since 2007, and a closer bond has developed among the STEM subjects, especially emphasizing 'the real life' context (Takeuchi et al. 2020), reciprocally connecting science, technology, engineering, and mathematics, as well as making connections between school, community, work, and the global enterprise enabling the development of STEM literacy and with it the ability to compete in the new economy (Tsupros et al., 2009). This means that the impact of STEM education can be viewed in the aspect of economics, politics, and culture (Hom, 2014), as well as common rationales for science education - the utilitarian: science knowledge needed for everyone, and the democratic: political and moral dilemmas of the contemporary society are of a scientific nature (Osborne \& Hennessy, 2003).

Integrated STEM education is one of the ways how to make learning more attractive and appropriate for learners (Stohlmann et al., 2012). However, it is still difficult to ensure that students are able to see the link among these subjects and to help them understand that information, processes and practice that are connected with these subjects are combined and used in the process of solving the real-life problems (Dass, 2015; Kelley \& Knowles, 2016). This means that one of the main reasons why students lose interest to acquire STEM is that, in general, the learning process seems boring to students which does not foster effective learning (Martínez-Borreguero et al., 2019). Motivating and engaging context, student-centered learning, focusing on teamwork and communication, can be considered the main elements of integrated STEM education (Moore et al., 2015). The more hands-on activities are used in the teaching/learning process, the more students' inquiry skills will be developed: to formulate the hypothesis, to experiment, to draw conclusions and to think analytically. Inquiry-based learning supported by information communication technology (Fiksl et al., 2017) increases students' interest. Inquiry-based learning is recognized as a very perspective model of active science teaching and learning, emphasizing that such studies need the interdisciplinary approach both in the empirical and theoretical fields, thus, ensuring better understanding (Gajić et al., 2021). Besides, the use of hands-on, active learning strategies in the teaching/learning process makes learning and the acquisition of knowledge easier (Martínez-Borreguero et al., 2019).

National education reform has been implemented in Latvia since 2020. Regarding the science domain, it takes place in four aspects: the promotion of cooperation in the acquisition of the teaching/learning content, the use of information and communication technologies (ICT) as a platform for developing reasoning and problem solving, experiential learning, which focuses on the process of discovery, and discussion-based teaching, which situates knowledge in the political and cultural context (Andersone, 2020).

Studies in Latvia have found that students of Grade 9 have a rather low level of cognitive interest in science, the majority of students have no desire to make any effort. A great part of students do not consider science and mathematics knowledge as personally relevant (Jurgena et al., 2018). This means that students' skills in these subjects need to be improved to increase their interest in continuing education in the fields in which they will have to acquire knowledge and skills important for the entrepreneurship and labor market, and which are more perspective in the context of future economics (NAP, 2020).

\section{Research Focus}

Continuity is one of the most important principles in pedagogy. Continuity is a concept which is used to describe 'the course of events, procedure of processes, transition of features, etc. that ensure the continuation, preservation of work, traditions and views of previous generations, predecessors and their further development in the life of the new generation, the formation of a similar social identity', as well as 'successive connection with something prior, a definite transition which observes the succession from the nearest to the farthest, from the 
Dagnija CEDERE, Inese JURGENA, Rita BIRZINA, Sandra KALNINA. Prospective pre-school teachers' views on STEM learning in grade 9: The principle of continuity in education

PROBLEMS

OF EDUCATION

IN THE $21^{\text {st }}$ CENTURY

Vol. 80 , No. 1,2022

understandable to the incomprehensible, from the easiest to more difficult, from unknown to the known, also gradualness' (Belickis et al., 2000, p. 125). The principle of continuity is employed in developing the teaching/learning curricula, Carr and Kemmis (2003) have explained it as a transition from one stage of education to the next, from the unknown to the known, as respect to the peculiarities of human development stages.

The nature of the principle of continuity is based on the philosophical ideas of Dewey about the connection of interaction and continuity (experience and education) with the quality of education. In one of his most famous articles on education, Dewey (1986, p. 12) has shared thoughts about the relations between experience and education, claiming that there is an organic link between experience and education because all experiences absorb something from the previous ones and transform the quality of experience which comes from them (Dewey, 1986, p. 27). It has been maintained that for the experience to have some educational value it must establish the growth, which creates further advancement. Therefore, education is the means of life, of social continuity (Dewey, 1997). Dewey $(1986$, p. 2) has postulated that growth which is defined as physical, intellectual, and moral development is the example of the principle of continuity.

Implementing changes in pre-school education and improving the quality of early childhood education, the necessity is actualized to focus, especially, on the early childhood stage (McCall, 2017; Vallberg-Roht, 2020) because a part of children, who now start attending the pre-school, will probably be employed in such jobs that do not exist yet (NAP, 2020). It is considered that it is possible to reach successful readiness of children or development of their adaptation skills in the transition from pre-school to school applying the mechanisms of complementing, which are understood as enriching and adding children's experience and knowledge to the instrumental social and cognitive priorities. For instance, academic learning is added to the game, children are asked to be responsible for success (Babic, 2017).

The principle of continuity actualizes correlations of theoretical thinking and productive imagination of the cognitive process of children's learning. Creative thinking is the basis of pre-school children's theoretical thinking therefore, the unity of productive imagination and creative thinking serves as a basis for the continuity between pre-school and school (Davydov \& Kudriavtsev, 1998), especially regarding the development of the content of the curricula and the ways of teacher collaboration for improving the quality of children's learning and teaching.

Lately, the number of studies about STEM education is rapidly increasing, however, little attention is paid to the STEM field at pre-school age (Takeuchi et al., 2020). Yet, the use of diverse practical and interesting science activities to develop children's inquiry skills and to promote their cognitive interest is highly recommended in pre-school education, and it is important to pay attention to exactly this level of societal education which can be a crucial contribution to increasing the population's scientific literacy and achievement (Brenneman, 2011).

Children possess immense inquisitiveness, thirst for knowledge and the skill to ask questions. The inquiry activity characteristic to a child fosters the development of inquisitiveness and inquiry activity. Children want to discover, explore, and understand the world and themselves. The task of early childhood teachers is to promote this curiosity ensuring relevant learning experience and engaging environment in the pre-school education institution (Howitt et al., 2011).

Children already in early childhood should be encouraged to observe different nature phenomena and to gain ideas about what is happening around, thus developing their curiosity about the world and obtaining knowledge in STEM fields. This means that ensuring positive experience in STEM education already in early childhood it is possible to promote cognitive interest about STEM, forming the conviction that they can gain success in STEM fields in future (Çiftçi et al., 2020). STEM education should be implemented as early as possible 
Dagnija CEDERE, Inese JURGENA, Rita BIRZINA, Sandra KALNINA. Prospective pre-school teachers' views on STEM learning in grade 9: The principle of continuity in education

PROBLEMS

OF EDUCATION

IN THE $21^{\text {st }}$ CENTURY Vol. 80 , No. 1,2022

because it helps children to develop scientific knowledge and form their scientific thinking. It is important that exact sciences are incorporated in the teaching/learning process in the way that corresponds to children's level of development. STEM education, certainly, is a challenge for very young children; teacher's task in this context is to make a link between 'ordinary' knowledge (knowledge about 'the real world') and scientific knowledge, between 'playing' and 'learning at school' (Surma et al., 2019).

Since September 1, 2020, comprehensive schools of Latvia have been gradually introducing curricula according to the new competence-based pre-school, basic and general secondary education standards, thus developing knowledge, skills, and attitudes necessary for the $21^{\text {st }}$ century (National Reforms in School Education, 2020). The principle of continuity has been followed in developing the teaching/learning content. Students during the basic education stage Grades $1-6$ acquire natural sciences in an integrated science subject and starting with Grade 7 in separate subjects - chemistry, physics, biology, and geography (Skola2030, 2019a). The aim of pre-school education is an inquisitive, creative, and joyful child who lives a healthy, safe, and active life, acts independently, learns with interest and joy gaining experience about oneself, others, the surrounding world, and the mutual interaction in it. Natural sciences in the pre-school curriculum, too, are very closely connected with mathematics and technology domains (Skola2030, 2019b, 2019c).

\section{Research Aim and Research Questions}

The new competence-based teaching/learning content of Latvia (National Reforms in School Education, 2020) connects the separate stages of general comprehensive education into a common, successive system, starting with the pre-school. Such a reciprocally coordinated approach is especially important in STEM education in order to initiate children's inquisitiveness already in pre-school so that later it grows into genuine cognitive interest. Therefore, the teacher of every stage of education has, to a certain extent, to be informed about the teaching/learning in the next stage of education. Grade 9 is the end of primary education and is often used to diagnose STEM learning achievements, so pre-school teachers' perceptions of STEM learning were focused on Grade 9.

The aim of the study was to find out the views of prospective pre-school teachers about STEM learning of Grade 9 students, thus also addressing the topical principle of continuity of education.

The following research questions were set:

1. What are prospective pre-school teachers' views about STEM learning?

2. How do prospective pre-school teachers understand STEM learning in the context of Grade 9?

\section{Research Methodology}

\section{General Background}

Studies performed in Latvia are indicative of the low prestige of STEM education the knowledge level of secondary school graduates in science and mathematics often is not sufficient for continuing their education (Birzina et al, 2021a), young adults' interest about STEM is low (Cedere et al., 2018). These factors, hindering the national development, actualize the study about STEM learning which is based on the idea about the continuity of education. Young adults' level of knowledge and attitude in the STEM field are closely connected with the teachers' professional competence, thus education of good teachers is also topical (NAP, 2020). 
Dagnija CEDERE, Inese JURGENA, Rita BIRZINA, Sandra KALNINA. Prospective pre-school teachers' views on STEM learning in grade 9: The principle of continuity in education

PROBLEMS

OF EDUCATION

IN THE $21^{\text {st }}$ CENTURY

Vol. 80 , No. 1,2022

The study is based on the survey of prospective pre-school teachers with the aim of finding out their views about STEM learning, focusing on pre-school teachers' awareness of STEM learning at the end of the next stage of education - in Grade 9. The survey connects two different stages of education, drawing prospective pre-school teachers' attention to the level of learning requirements in Grade 9. Thus, skills and attitudes characteristic to the STEM field are viewed in the context of continuity of education.

The survey was carried out in autumn of 2021.

\section{Sample}

The study has involved first year students of the University of Latvia - prospective pre-school teachers. The total number of first year students studying to become pre-school teachers was 306 , of them 261 or $85 \%$ participated in the survey. This sample that reflects the characteristics of the entire student group was representative to consider the survey reliable and to arrive at valid conclusions.

Almost all the participants were women, namely 259, and 2 were men, which is less than $1 \%$. All respondents were part-time students and represented different regions of Latvia, of them $26 \%$ studied in Riga, and $74 \%$ - in one of the seven regional branches of the University of Latvia.

The average age of respondents was 33 years, the age bracket being 19-57 years. It is important to mention that $30 \%$ of respondents, mainly older students, who want to obtain the teacher qualification, have already work experience with pre-school children.

In order to make a comparison according to the respondents' age group and more obvious, three age groups were established: Group A (19-30 years), Group B (31-40 years), and Group C (41 and more) (Table 1).

Table 1

Distribution of Respondents per Age Group

\begin{tabular}{lccc}
\hline Group & Age (years) & $\boldsymbol{N}$ & $\%$ \\
\hline A & $19-30$ & 99 & 38 \\
\hline B & $31-40$ & 115 & 44 \\
\hline C & $41-57$ & 47 & 18 \\
\hline Total & $19-57$ & 261 & 100 \\
\hline
\end{tabular}

Instrument and Procedures

The study used a survey in which prospective pre-school teachers expressed their views about STEM learning. The questionnaire was developed based on the previous studies (Cedere et al., 2018) and in compliance with the normative documents in Latvia (National Reforms in School Education, 2020).

The questionnaire comprises 21 close-ended questions on 4- point Likert scale (from 1 fully disagree to 4 -fully agree) and 5 open questions. The closed questions are subordinated to the common basic question: How should Grade 9 students answer the given questions according to education provisions and national needs? Questions that are given in a mixed order include also two learning aspects - the learning process (Block A) and cognitive interest (Block B). Block A comprises questions that describe the learning skills and attitudes and Block B contains questions from different STEM subjects that are thematically connected with nature exploration and everyday life. The reliability (inter-item consistency) of the questionnaire according to 
Dagnija CEDERE, Inese JURGENA, Rita BIRZINA, Sandra KALNINA. Prospective pre-school teachers' views on STEM learning in grade 9: The principle of continuity in education

PROBLEMS

OF EDUCATION

IN THE $21^{\text {st }}$ CENTURY Vol. 80 , No. 1,2022

Cronbach's alpha coefficient was .87. The previous studies (Cedere et al., 2018) confirm the validity of the questionnaire.

The questionnaire was made using google.doc. Students filled in the questionnaire online. Students' participation in the survey was voluntary, the anonymity of the survey was guaranteed.

\section{Data Analysis}

The Cronbach's alpha test was used to determine the internal consistency of the questionnaire.

Indicators of descriptive statistics - mean and standard deviation were used to describe the empirical data. Applying one sample Kolmogorov-Smirnov test, it was established that the distribution of empirical data did not correspond to the normal distribution $(p<.005)$ therefore non-parametric statistical methods were used in the data analysis. Spearman rank correlation was used to define the degree of association between two variables. The Kruskal-Wallis $H$ test was used to compare three independent groups.

\section{Research Results}

The learning content connected with practical life and nature, inquiry skills and attitude were used in the questionnaire to describe Grade 9 students' attitudes to STEM. Prospective pre-school teachers answered the questions of the questionnaire showing their understanding of the general education model currently existing in Latvia and remembering their school years.

Table 2 presents summarized data about Block A questions that describe respondents' views about the anticipated Grade 9 students' attitude to STEM, about skills acquired at school as well as the learning intensity. Mean values of answers are arranged in increasing order.

\section{Table 2}

STEM Learning of Grade 9 Students: Views of Prospective Pre-school Teachers

\begin{tabular}{lllll}
\hline No & Items & Variables & $\boldsymbol{M}$ & $\mathbf{S D}$ \\
\hline 1 & A11 & Exploration in the leisure time & 2.40 & 0.81 \\
\hline 2 & A5 & Problem-solving skill & 2.80 & 0.66 \\
\hline 3 & A8 & Enthusiasm, perseverance & 2.87 & 0.84 \\
\hline 4 & A4 & The skill to analyze & 2.98 & 0.67 \\
\hline 5 & A3 & The skill to explain & 2.98 & 0.72 \\
\hline 6 & A10 & Overcoming difficulties & 3.14 & 0.78 \\
\hline 7 & A9 & Interest resulting from inquiry & 3.20 & 0.72 \\
\hline 8 & A13 & Understanding about the importance of STEM & 3.53 & 0.67 \\
\hline $1 \leq M \leq 4$ & & &
\end{tabular}

Answers of prospective pre-school teachers showed that they acknowledged inquiry skills, including the skill to analyze and evaluate, as important. They valued equally highly the perseverance in learning and not being afraid of difficulties. These, certainly, are important in the process of learning STEM.

The importance of STEM knowledge in the national development is valued the highest (A13, $M=3.53, S D=0.67$ ), it points to the homogeneity of views and at the same time 
Dagnija CEDERE, Inese JURGENA, Rita BIRZINA, Sandra KALNINA. Prospective pre-school teachers' views on STEM learning in grade 9: The principle of continuity in education

PROBLEMS

OF EDUCATION

IN THE $21^{\text {st }}$ CENTURY

Vol. 80 , No. 1,2022

describes prospective teachers' good understanding of the new education model in Latvia. Grade 9 students are expected to develop interest in the process of exploration (A9), though meaning with it the performance in lessons. The relatively low values of standard deviations in these questions also indicate a rather big consensus of respondents.

Exploration in the leisure time is evaluated the lowest $(M=2.40)$. Respondents' distribution showed that $14 \%$ fully disagree, and 35\% respondents - rather disagree, which together constitutes almost half of the total number of respondents.

Views of prospective pre-school teachers on the desirable Grade 9 students' cognitive interest are reflected in Table 3, which summarizes the data about Block B questions. Mean values of answers are arranged in increasing order.

\section{Table 3}

Cognitive Interest in STEM of Grade 9 Students: Views of Prospective Pre-school Teachers

\begin{tabular}{lllll}
\hline No & & Variables & M & SD \\
\hline 1 & B8 & Liked to use mathematical equations in solving practical tasks & 2.26 & 0.87 \\
\hline 2 & B5 & Willingness to understand why the soap solution is not clear & 2.98 & 0.96 \\
\hline 3 & B4 & Interest in using modified organisms & 3.19 & 0.83 \\
\hline 4 & B6 & Willingness to find out why the glass container breaks if water freezes in it & 3.34 & 0.83 \\
\hline 5 & B3 & Interest in the structure and functions of the human organism & 3.48 & 0.68 \\
\hline 6 & B1 & Interest why the air after the thunderstorm smells differently & 3.55 & 0.71 \\
\hline 7 & B7 & Willingness to know how drinking water is purified & 3.59 & 0.62 \\
\hline
\end{tabular}

$1 \leq M \leq 4$

In general, prospective pre-school teachers considered the cognitive interest important. Besides, there are no sharp differences among respondents' answers $(S D<1)$ in this block of answers, too, which proves that the majority of respondents have similar views. Respondents' views differed depending on the content of the question and STEM thematic field. High school students' interest is anticipated about the question related to what is happening in the nature the smell of the air after the thunderstorm because without delving into the requirements for Grade 9 the question seems very simple (B1). Equally high interest is foreseen if the question is connected with the purification of drinking water (B7), which is important from the point of view of daily life. High cognitive interest is envisaged also about daily processes if they are connected with biology, chemistry or physics. However, much lower interest is anticipated if the task is connected with mathematics (B8, $M=2.26, S D=0.87)$.

\section{Comparison of Prospective Teachers' Views Depending on Their Life Experience}

The Kruskal Wallis $H$ Test was performed to find out if the differences in prospective teachers' views can be linked to their life experience. Respondents' answers were compared according to the three age groups. The obtained results showed that the answers given by respondents of different age groups to the majority of questions were similar and there were no statistically significant differences among them. Only results that demonstrate significant differences among age groups are summarized in Table 4. 
Dagnija CEDERE, Inese JURGENA, Rita BIRZINA, Sandra KALNINA. Prospective pre-school teachers' views on STEM learning in grade 9: The principle of continuity in education

OF EDUCA IN THE $21^{\text {st }}$ CENTURY Vol. 80 , No. 1,2022

Table 4

Differences in Views of Prospective Pre-school Teachers Depending on Their Age

\begin{tabular}{|c|c|c|c|c|c|c|c|c|c|}
\hline \multirow{2}{*}{ Items } & \multicolumn{2}{|c|}{$\begin{array}{l}\text { Group A ( } n=99) \\
\text { (age 19-30 years) }\end{array}$} & \multicolumn{2}{|c|}{$\begin{array}{l}\text { Group B ( } n=115) \\
\text { (age 31-40 years) }\end{array}$} & \multicolumn{2}{|c|}{$\begin{array}{l}\text { Group C ( } n=47) \\
\text { (age } 40+\text { years) }\end{array}$} & \multirow{2}{*}{$\chi^{2}$} & \multirow{2}{*}{$d f$} & \multirow{2}{*}{$p$} \\
\hline & $M$ & SD & $M$ & SD & $M$ & SD & & & \\
\hline A11 & 2.20 & 0.82 & 2.53 & 0.79 & 2.51 & 0.78 & 10.162 & 2 & .006 \\
\hline $\mathrm{A} 13$ & 3.39 & 0.75 & 3.64 & 0.55 & 3.55 & 0.69 & 6.345 & 2 & .042 \\
\hline B3 & 3.43 & 0.70 & 3.44 & 0.68 & 3.68 & 0.63 & 6.622 & 2 & .036 \\
\hline B4 & 3.03 & 0.85 & 3.25 & 0.80 & 3.38 & 0.80 & 7.517 & 2 & .023 \\
\hline
\end{tabular}

As seen in Table 4, the prospective teachers with greater life experience (Group B and Group C), value higher cognitive activities in time free from school (A11). They better understand learning outcomes in Grade 9 that also include deep enough knowledge in biology knowledge about human organism (B3) and about the use of modified organisms (B4). Group $\mathrm{B}$ has the highest conviction about the importance of STEM knowledge in the national development (A13), where the dispersion of answers is small $(M=3.64 ; S D=0.55)$.

\section{Didactic Connection among STEM Subjects}

In order to establish what connection is among separate characteristic features of STEM teaching and learning, the correlation analysis according to Spearman's correlation coefficients was performed. Using the whole sample of respondents, only weakly statistically significant correlations were found, but such a result was of little information. Using the variable like mathematics' (B8), for which the mean value of answers was the lowest, respondents were selected who had answered 'fully agree' about mathematics, thus with a potentially good understanding about STEM learning. A group of 19 respondents was separated $(7.3 \%$ of the total number), for which the correlation analysis was performed according to 7 most important STEM learning criteria (Table 5).

Table 5

Correlations among Variables that Describe STEM Learning

\begin{tabular}{llllllll}
\hline Variables & A3 & A4 & A5 & A6 & A8 & A10 & A13 \\
\hline The skill to explain (A3) & 1 & $.55^{*}$ & .36 & .17 & .29 & .43 & .59 \\
\hline The skill to analyze (A4) & & 1 & $.50^{*}$ & $.50^{*}$ & .26 & $.60^{* *}$ & .32 \\
\hline Problem-solving skill (A5) & & 1 & $.76^{* *}$ & .25 & $.80^{* *}$ & .30 \\
\hline The skill predict (A6) & & & 1 & .35 & $.64^{* *}$ & .20 \\
\hline Enthusiasm, perseverance (A8) & & & & & .29 & $.48^{*}$ \\
\hline Overcoming difficulties (A10) & & & & & .35 \\
\hline Understanding about the importance of \\
STEM (A13) \\
${ }^{*}$ Correlation is significant at the .05 level (2-tailed). \\
${ }^{* *}$ Correlation is significant at the .01 level (2-tailed).
\end{tabular}

The correlation analysis showed that respondents, who were aware of the importance of mathematics to solve problem tasks in science according to the level of requirements in Grade 
Dagnija CEDERE, Inese JURGENA, Rita BIRZINA, Sandra KALNINA. Prospective pre-school teachers' views on STEM learning in grade 9: The principle of continuity in education

PROBLEMS

OF EDUCATION

IN THE $21^{\text {st }}$ CENTURY

Vol. 80 , No. 1,2022

9 (Skola2030, 2019a), saw a close relation between overcoming the difficulties (A10) and the acquired skills: the skill to solve problems (A5, $\left.r_{s}=.80\right)$, the skill to analyze (A4, $\left.r_{s}=.60\right)$, the skill to predict $\left(\mathrm{A} 6, r_{s}=.64\right)$. There is also a close relation $\left(r_{s}=.48\right)$ between the understanding about the importance of STEM and perseverance (A8), which is vitally necessary for every learner in the acquisition of science and mathematics.

\section{Discussion}

Learning by doing is characteristic in STEM acquisition. The use of practical real-life examples, inquiry and experimental teaching/learning methods, the project-based and problemsolution-based approach, modelling and visualization - such a many-sided approach - forms students' holistic understanding of STEM (Birzina et al., 2021a; Birzina et al., 2021b).

At the same time, it should be mentioned that pluralism of views describes the generation of the $21^{\text {st }}$ century - different views about the importance of natural sciences, about whether STEM should be learnt only at school, or it should be related to everyday life. Not taking into consideration the diversity of students, differences in their thinking, opinions and learning styles, the shortcomings of the interdisciplinary teaching/learning process are confirmed. Certain tolerance towards young adults' personal views is needed in order to achieve that STEM learning becomes meaningful and personally significant for every student (Cedere et al., 2020).

Expressing the understanding about the importance of STEM knowledge in the national development, learning with interest is expected from Grade 9 students, mainly meaning their performance/action in lessons, but not in the free time from school. Almost half of prospective teachers did not consider that exploration in the leisure time is important, thus they did not see how big importance there was if the student, observing nature and processes in real life, was able to apply the knowledge acquired at school and had interest about it. Linking the teaching/ learning content with real life by no means should be restricted to the frame of the lesson. Just on the contrary, the aim of STEM education is to develop every learner's skill, necessary for practical real life. STEM develops thinking, creativity, problem solving skills that are needed for the emergence of new researchers, explorers, inventors, specialists of the many technical spheres who would be able to solve the problems of today's world (Maass et al., 2019).

Comparing the data about prospective teachers' views with results of Latvian students in the OECD PISA study in 2018 (Geske et al., 2020), a similar feature can be observed. Students lack content and epistemic knowledge or skills to apply this knowledge for solving more difficult tasks, the prospective teachers, in turn, under-appreciate such knowledge. Probably, the views of many prospective pre-school teachers about what Grade 9 students must know and be able to do, have been influenced by not a sufficient analytical approach to separate the level of teaching/learning requirements according to the respective age group, i.e., pre-school and basic school.

Integration of science subjects largely is based on the research elements (Moore et al., 2015). Skills - to analyze, evaluate, and solve problems connected with practical life require complex knowledge from Grade 9 students, including also the skill to solve mathematical tasks (Andersone, 2020). Mathematics is not an easy subject for everyone, but a good teacher will find a way how to help the learner to succeed. Teacher's passivity cannot be supported in this aspect (Respondent A: Mathematics should be left as it is because either you understand it or not). Unfortunately, the data show that many other respondents could have similar thoughts about it because the indicator of cognitive interest of mathematics is the lowest $(M=2.26, S D=$ 0.87). Comparing the data with the previous Grade 9 students' survey (Cedere et al., 2018), it is possible to state that students' attitude to mathematics answering the same question is equally low $(M=2.25 ; S D=1.15)$. Only $7 \%$ of the surveyed prospective pre-school teachers are convinced that in order to solve some problem tasks in biology, chemistry or physics in Grade 9, students need to have deep enough knowledge in mathematics. 
Dagnija CEDERE, Inese JURGENA, Rita BIRZINA, Sandra KALNINA. Prospective pre-school teachers' views on STEM learning in grade 9: The principle of continuity in education

PROBLEMS

OF EDUCATION IN THE $21^{\text {st }}$ CENTURY Vol. 80 , No. 1,2022

Following the correlation analysis, those respondents who value highly the importance of mathematics skills are also certain that one can succeed in the STEM learning process only overcoming the difficulties. The correlation analysis proves that only a part of prospective teachers have a good understanding about the relation between STEM subjects as well as between the characteristic features of STEM learning - inquiry skills, perseverance and not being afraid of difficulties.

Integration of STEM subjects is a way how to make learning meaningful for students (Stohlmann et al., 2012; Takeuchi et al., 2020). Prospective pre-school teachers with more life experience have a more explicit understanding about deep learning of STEM subjects. They consider important the interest about the structure and functions of the human organism, the use of modified organisms in food production and medicine.

Learning with interest is especially important in STEM subjects, which seem difficult for many students, and therefore learning of these subjects requires certain effort (Jurgena et al., 2018; Osborne et al., 2003). High evaluation of cognitive interest and understanding about STEM teaching/learning methods is proven by respondents' answers to the open questions (Respondents B: To my mind, the main way how to stir students' interest in science is to make the learning process more practical and exciting, showing students how actually common and valuable this knowledge can be. Let everyone who learns science have joy, inspiration, and many creative ideas)

Comparing the data with the previous Grade 9 students' survey (Cedere et al., 2018), it is possible to see that prospective teachers feel more responsible as regards STEM learning, and they value much higher the cognitive interest.

The use of hands-on, practical, interest-stimulating methods that make the learning easier (Martínez-Borreguero et al., 2019), is also highly appreciated by respondents (Respondents $C$ : ...so that children are not bored in lessons, but are truly interested, experiment, explore. One should learn and again learn to achieve something).

The results of the study confirm the close connection between the teachers' methods of teaching and students' academic performance, emphasizing the principle of continuity in education which gives the prospective teachers a more comprehensive idea about the STEM education process in general.

The performed study has some limitations. This can be viewed as a pilot study therefore the obtained results should be treated as tentative. The study refers to exploring the views of first year students of the University of Latvia - prospective pre-school teachers, thus the results cannot be assessed and interpreted in a broader context.

\section{Conclusions and Implications}

Performing the study, it has been established that the prospective pre-school teachers considered cognitive interest and active, inquiry-based learning as especially important in STEM education. The importance of STEM knowledge for the national development has been highly assessed, and the respondents with more life experience have admitted it with greater certainty. The study allowed stating that the prospective pre-school teachers have a general idea about STEM learning in Grade 9 of the basic school; however, they have not assessed high enough the mathematical skills. It is essential that the prospective pre-school teachers have noticed the connection between STEM learning and such important character features as perseverance and not avoiding the difficulties.

The present study has given a possibility to understand better the prospective pre-school teachers' needs in order to improve the teacher education programs at the university. The prospective pre-school teachers need to have the idea about the STEM learning in the next stage of education to develop a better successive link between the pre-school and further schooling, 
Dagnija CEDERE, Inese JURGENA, Rita BIRZINA, Sandra KALNINA. Prospective pre-school teachers' views on STEM learning in grade 9: The principle of continuity in education

thus making the children's learning easier. Continuing the study in the context of continuity in education, the authors envisage focusing more on the coordination of the teaching/learning content of separate stages of education.

\section{Declaration of Interest}

The authors declare no competing interest.

\section{References}

Andersone, R. (2020). Innovations in the improved curriculum content of the competence approach: A case study in Latvia. In V. Dislere (Ed.), The Proceedings of the International Scientific Conference Rural Environment. Education. Personality (REEP) (pp. 213-218). Latvia University of Life Sciences and Technologies https://doi.org/10.22616/REEP.2020.025

Babic, N. (2017). Continuity and discontinuity in education: Example of transition from pre-school to school. Early Child Development and Care, 187(10), 1596-1609. https://doi.org/10.1080/03004430.2017.1301935

Barcelona, K. (2014). 21st century curriculum change initiative: A focus on STEM education as an integrated approach to teaching and learning. American Journal of Educational Research, 2(10), 862-875.

Belickis, I., Blūma, D., Koḳe, T., Markus, D., Skujiņa, V., \& Šalme, A. (2000). Pedagogijas terminu skaidrojoša $\bar{a}$ ârdnīca [Dictionary of pedagogical terms]. Apgāds Zvaigzne ABC.

Binkley, M., Erstad, O., Herman, J., Raizen, S., Ripley, M., Miller-Ricci, M., \& Rumble, M. (2012). Defining twenty-first century skills. In P. Griffin, B. McGaw, E. Care (Eds.), Assessment and teaching of 21st century skills (pp. 17-66). Springer.

Birzina, R., Pigozne, T., \& Cedere, D. (2021a). Students' readiness for STEM learning within the context of national education reform. In L. Daniela (Ed.), Human, Technologies and Quality of Education (pp. 657-752). LU Akadēmiskais apgāds.

Birzina, R., Pigozne, T., \& Lapina, S. (2021b). Trends in STEM teaching and learning within the context of national education reform. In V. Dislere (Ed.), The Proceedings of the International Scientific Conference Rural Environment. Education. Personality (REEP) (pp. 41-49). Latvia University of Life Sciences and Technologies. https://doi.org/10.22616/REEP.2021.14.004

Brenneman, K. (2011). Assessment for pre-school science learning and learning environments. Early Childhood Research \& Practice, 13(1), 1-9. https://files.eric.ed.gov/fulltext/EJ931225.pdf

Carr, W., \& Kemmis, S. (2003). Becoming critical: Education, knowledge and action research. Routledge.

Cedere, D., Birzina, R., Pigozne, T., \& Vasilevskaya, E. (2020). Perceptions of today's young generation about meaningful learning of STEM. Problems of Education in the 21st Century, 78(6), 920-932. https://doi.org/10.33225/pec/20.78.920

Cedere, D., Jurgena, I., \& Targamadze, V. (2018). Interest of Latvian and Lithuanian students in science and mathematics. Journal of Baltic Science Education, 17(1), 31 42. https://doi.org/10.33225/jbse/18.17.31

Çiftçi, A., Topçu, M. S., \& Foulk, J. A. (2020). Pre-service early childhood teachers' views on STEM education and their STEM teaching practices. Research in Science \& Technological Education. https://doi.org/10.1080/02635143.2020.1784125

Dass, P. (2015). Teaching STEM effectively with the learning cycle approach. K-12 STEM Education, 1(1), 5-12. https://doi.org/10.33225/pec/21.79.728

Davydov, V. V., \& Kudriavtsev, V. T. (1998). Development education. Russian Education and Society, 40(7), 37-64. https://doi.org/10.2753/RES1060-9393400737

Dewey, J. (1986). Experience and education. The Educational Forum, 50(3), 241-252. https://doi.org/10.1080/00131728609335764

Dewey, J. (1997). Democracy and education: An introduction to the philosophy of education. The Project Gutenberg. https://www.gutenberg.org/ebooks/852

Fiksl, M., Flogie, A., \& Aberšek, B. (2017). Innovative teaching/learning methods to improve science, technology and engineering classroom climate and interest. Journal of Baltic Science Education, 16(6), 1009-1019. https://doi.org/10.33225/jbse/17.16.1009 
Dagnija CEDERE, Inese JURGENA, Rita BIRZINA, Sandra KALNINA. Prospective pre-school teachers' views on STEM learning in grade 9: The principle of continuity in education

PROBLEMS

OF EDUCATION IN THE $21^{\text {st }}$ CENTURY Vol. 80 , No. 1,2022

Eurydice Report. (2019). Key data on early childhood education and care in Europe. Publications Office of the European Union. https:/eacea.ec.europa.eu/national-policies/eurydice/sites/default/files/ ec0319375enn_0.pdf.

Gajić, M. M., Županec, V. D, Babić-Kekez, S. S., \& Trbojević, A. R. (2021). Methodological approaches to the study of inquiry-based learning in natural science education. Problems of Education in the 21st Century, 79(5), 728-750. https://doi.org/10.33225/jbse/21.20.184

Geske, A., Grīnfelds, A., Kangro, A., Kisel̦ova, R., \& Stūre, B. (2020). Latvijas skolēnu sasniegumi un skolas vide OECD PISA salīdzinājumā [Latvian students' performance and school environment in OECD PISA comparison] In A. Kangro (Ed.) Educational Research in Latvia, Monograph 11. University of Latvia, Faculty of Pedagogy, Psychology and Art, Educational Research Institute. https://www.ipi.lu.lv/fileadmin/user_upload/lu_portal/projekti/ipi/PISA/ PISA2015 sekundarie petijumi.pdf

Hom, E. J. (2014). What is STEM education? https://www.livescience.com/43296- what-is-stemeducation.html

Howitt, C., Lewis, S., \& Upson, E. (2011). 'It's a mystery': A case study of implementing forensic science in pre-school as scientific inquiry. Australasian Journal of Early Childhood, 36(3), 4555. https://doi.org/10.1177/183693911103600307

Jurgena I., Cedere D., \& Keviša, I. (2018). The Prospects of transdisciplinary approach to promote learners' cognitive interest in natural science for sustainable development. Journal of Teacher Education for Sustainability, 20(1), 5-19. https://doi.org/10.2478/jtes-2018-0001

Kelley, T.R., \& Knowles, J. G. (2016). Aconceptual framework for integrated STEMeducation. International Journal of STEM Education, 3(1), 1-11. https://doi.org/10.1186/s40594-016-0046-z

Maass, K., Geiger, V., Ariza, M. R., \& Goos, M. (2019). The role of mathematics in interdisciplinary STEM education. ZDM, 51(6), 869-884. https://doi.org/10.1007/s11858-019-01100-5

Martínez-Borreguero, G., Mateos-Núñez, M., \& Naranjo-Correa, F. L. (2019). Implementation and didactic validation of STEM experiences in primary education: Analysis of the cognitive and affective dimension. In Theorizing STEM Education in the 21st Century. IntechOpen. http://dx.doi.org/10.5772/intechopen.88048

McCall, J. (2017). Continuity and change in teacher education in Scotland-back to the future. European Journal of Teacher Education, 40(5), 601-615. https://doi.org/10.1080/02619768.2017.1385059

Moore, T. J., Johnson, C. C., Peters-Burton, E. E., \& Guzey, S. S. (2015). The need for a STEM roadmap. In C. C. Johnson, E. E. Peters-Burton, \& T. J. Moore (Eds.), STEM road map: A framework for integrated STEM education (pp. 3-12). Routledge.

NAP. (2020). Nacionālais attīstības plāns 2021. - 2027. gadam [National development plan for 20212027]. https://www.pkc.gov.lv/sites/default/files/inline-files/20200204_NAP_2021_2027_gala_ redakcija_projekts_.pdf

National Reforms in School Education. (2020). https://eacea.ec.europa.eu/national-policies/eurydice/ content/national-reforms-school-education-34_en

Osborne, J., \& Hennessy, S. (2003). Literature review in science education and the role of ICT: Promise, problems and future directions. Futurelab. https://telearn.archives-ouvertes.fr/hal-00190441

Osborne, J., Simon, S., \& Collins, S. (2003). Attitudes towards science: A review of the literature and its implications. International Journal of Science Education, 25(9), 1049-1079. https://doi.org/10.1080/0950069032000032199

Skola2030. (2019a) Dabaszinätnes [Science]. https://www.skola2030.lv/lv/macibu-saturs/macibu-jomas/ dabaszinatnes

Skola2030. (2019b) Pirmsskola [Pre-school]. https://www.skola2030.lv/lv/istenosana/izglitibas-pakapes/ pirmsskola

Skola2030. (2019c). Pirmsskolas mācību programma [Pre-school curriculum]. https://mape.skola2030. lv/resources/10

Stohlmann, M., Moore, T. J., \& Roehrig, G. H. (2012). Considerations for teaching integrated STEM education. Journal of Pre-College Engineering Education Research, 2, 28-34. https://doi.org/10.5703/1288284314653

Surma, B., Rosati N., Menon, S., Fuertes, M. T., Farren, M., \& Maguire, F. (2019). Kitchen lab for kids: A programme for shaping STEM skills in pre-school. Edukacja Elementarna $w$ Teorii i Praktyce, 14(4), 61-70. https://doi.org/10.35765/eetp.2019.1454.05 
Dagnija CEDERE, Inese JURGENA, Rita BIRZINA, Sandra KALNINA. Prospective pre-school teachers' views on STEM learning in grade 9: The principle of continuity in education

PROBLEMS

OF EDUCATION

IN THE $21^{\text {st }}$ CENTURY

Vol. 80 , No. 1,2022

Takeuchi, M. A., Sengupta, P., Shanahan, M-C., Adams, J. D., \& Hachem, M. (2020) Transdisciplinarity in STEM education: A critical review. Studies in Science Education, 56(2), 213-253. https://doi.org/10.1080/03057267.2020.1755802

Tsupros, N., Kohler, R., \& Hallinen, J. (2009). STEM education: A project to identify the missing components. Leonard Gelfand Center for Service Learning and Outreach at Carnegie Mellon University, and The Intermediate Unit 1 Center for STEM Education. https://www.cmu.edu/ gelfand/documents/stem-survey-report-cmu-iu1.pdf

Tytler R. (2020). STEM education for the twenty-first century. In J. Anderson \& Y. Li (Eds.), Integrated Approaches to STEM Education. Advances in STEM Education (pp. 21-43). Springer. https://doi.org/10.1007/978-3-030-52229-2_3

Received: January 02, 2022

Accepted: February 12, 2022

Cite as: Cedere, D., Jurgena, I., Birzina, R., \& Kalnina, S. (2022). Prospective pre-school teachers' views on STEM learning in grade 9: The principle of continuity in education. Problems of Education in the $21^{\text {st }}$ Century, 80(1), 69-81. https://doi.org/10.33225/pec/22.80.69

\begin{tabular}{|ll|}
\hline $\begin{array}{l}\text { Dagnija Cedere } \\
\text { (Corresponding author) }\end{array}$ & $\begin{array}{l}\text { Dr.chem., Associate Professor, University of Latvia, Jelgavas iela 1, Riga } \\
\text { LV-1004, Latvia. } \\
\text { E-mail: dagnija.cedere@lu.lv } \\
\text { ORCID: https:///orcid.org/0000-0002-6654-3054 }\end{array}$ \\
\hline Inese Jurgena & $\begin{array}{l}\text { Dr.paed., Professor, University of Latvia, Imantas 7.linija, Riga LV-1083, } \\
\text { Latvia. } \\
\text { E-mail: inese.jurgena@lu.lv } \\
\text { ORCID: https://orcid.org/0000-0002-1862-110X }\end{array}$ \\
\hline Rita Birzina & $\begin{array}{l}\text { Dr.paed, Leading Researcher, University of Latvia, Jelgavas iela 1, Riga, } \\
\text { LV-1004, Latvia } \\
\text { E-mail: rita.birzina@lu.lv } \\
\text { ORCID: https://orcid.org/0000-0002-6124-1073 }\end{array}$ \\
\hline Sandra Kalnina & $\begin{array}{l}\text { Mg.paed., Mg.phil., Lecturer, University of Latvia, Imantas 7.linija, Riga } \\
\text { LV-1083, Latvia. } \\
\text { E-mail: sandra.kalnina@lu.lv }\end{array}$ \\
\hline
\end{tabular}

